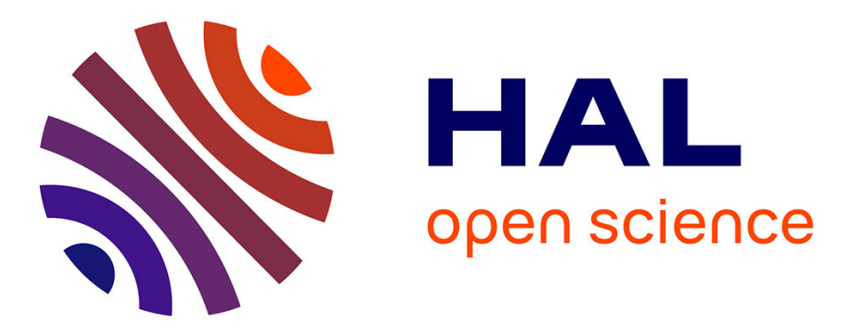

\title{
Preface New trends in supercritical fluids: Energy; materials; processing. A special issue-9th International Symposium on Supercritical Fluids, May 18-20, 2009, Arcachon, France
}

Jacques Fages, Cyril Aymonier, François Cansell, Jacques Mercadier

\section{To cite this version:}

Jacques Fages, Cyril Aymonier, François Cansell, Jacques Mercadier. Preface New trends in supercritical fluids: Energy; materials; processing. A special issue-9th International Symposium on Supercritical Fluids, May 18-20, 2009, Arcachon, France. Journal of Supercritical Fluids, 2010, 53 (1-3, SI), p.1. 10.1016/j.supflu.2010.02.003 . hal-01618295

\section{HAL Id: hal-01618295 \\ https://hal.science/hal-01618295}

Submitted on 7 Feb 2018

HAL is a multi-disciplinary open access archive for the deposit and dissemination of scientific research documents, whether they are published or not. The documents may come from teaching and research institutions in France or abroad, or from public or private research centers.
L'archive ouverte pluridisciplinaire HAL, est destinée au dépôt et à la diffusion de documents scientifiques de niveau recherche, publiés ou non, émanant des établissements d'enseignement et de recherche français ou étrangers, des laboratoires publics ou privés. 
Preface

\section{New trends in supercritical fluids: Energy; materials; processing. A special issue-9th International Symposium on Supercritical Fluids, May 18-20, 2009, Arcachon, France}

This special issue is entirely devoted to the 9th ISSF conference. A thorough selection of the best papers presented at this conference has been peer-reviewed and will hopefully serve as a reference for all the students, professors and researchers active in this area into the foreseeable future.

More than twenty years ago, the International Society for the Advancement of Supercritical Fluids (ISASF) launched this series of conferences and the first ISSF symposium was held in Nice, France in 1988. Since then, every three years, this symposium has become the privileged location to review the vigorous developments in supercritical fluids research.The previous conferences were held in:

- 1st Nice, France 1988;

- 2nd Boston, USA 1991;

- 3rd Strasbourg, France 1994;

- 4th Sendai, Japan 1997;

- 5th Atlanta, USA 2000;

- 6th Versailles, France 2003;

- 7th Orlando, USA 2005;

- 8th Kyoto, Japan 2006.

The ninth event in this series was co-organized by three French laboratories ICMCB-CNRS (Solid State Chemistry and Materials Science) in Bordeaux, LaTEP (Chemical Engineering) in Pau and RAPSODEE (Particle Science and Waste Valorisation) in Albi, under the auspices of ISASF.

In spite of the global economic crisis and the swine flu pandemic, which prevented some colleagues from coming, it brought together more than 300 participants from 36 countries to Arcachon, the famous French seaside resort.

The aim of the organizers was to focus on new fields of development in supercritical science and technology. Topics covered by the conference ranged from issues related to basic research to industrial development of new technologies and processes. The scope of this conference has demonstrated the richness of this ever-growing domain.

Three plenary lecturers - from Europe, America and Asia respectively - opened each day by giving an enlightening overview on three major disciplines: the thermophysics of supercritical fluids, nanomaterials synthesis and waste valorisation. Each of the $15 \mathrm{sci}-$ entific sessions was launched by a keynote lecture introducing the domain. On the whole, there were 293 scientific communications. Throughout the three-day meeting, presentations and discussions highlighted significant topics. Some of them have been active for one or two decades now, for example: thermophysical properties, extraction of natural products, particle generation and design and hydrothermal waste valorisation. Some others are more recent and have rapidly developed: green chemistry in supercritical medium, composite materials, nanostructured catalysts synthesis, new fuels from SCF, to name just a few.

This special issue showcases the most remarkable research works presented in Arcachon, giving an up-to-date panorama of the advancement of research and indicating the most promising ways ahead. We hope that this will become an important and welcome addition to the growing body of work in the field.

Finally, we are pleased to announce that the next conference in this successful series will be held in San Francisco, USA in 2012. We wish this upcoming event as much success as its predecessors have enjoyed and we cordially say "see you in "Frisco" to all the readers of this special issue.

Jacques Fages* RAPSODEE Research Centre, Ecole des Mines, Campus Jarlard, 81013 Albi, France

Cyril Aymonier ICMCB-CNRS, Pessac, France

François Cansell IPB, Pessac, France Jacques Mercadier LATEP, Pau, France

* Corresponding author. Tel.: +33 563493 141; fax: +33563493025.

E-mail addresses: Jacques.Fages@mines-albi.fr (J. Fages), aymonier@icmcb-bordeaux.cnrs.fr (C. Aymonier), cansell@ipb.fr (F. Cansell), jacques.mercadier@univ-pau.fr (J. Mercadier) 